\title{
EFEKTIVITAS MODEL PEMBELAJARAN GUIDED DISCOVERY LEARNING TERHADAP HASIL BELAJAR MATEMATIKA
}

\author{
Witri Lestari \\ Program Studi Pendidikan Matematika,Universitas Indraprasta PGRI Jakarta \\ Email: witrilestari.unindra@gmail.com
}

\begin{abstract}
ABSTRAK
Tujuan Penelitian adalah untuk mengetahui efektivitas penggunaan model pembelajaran guided discovery learning terhadap hasil belajar matematika pada ranah kognitif. Metode penelitian yang digunakan adalah quasi experiment atau eksperimen semu dengan desain penelitian non-equivalent control grup. Jumlah sampel dalam penelitian adalah 46 yang terbagi atas 23 sampel untuk kelas eksperimen dan 23 sampel untuk kelas kontrol. Teknik sampling yang digunakan adalah teknik nonrandom. Jenis instrumen yang digunakan adalah tes dalam bentuk soal uraian sebanyak 10 butir. Hasil uji penelitian menunjukan diterima $H_{1}$, yaitu adanya perbedaan antara rata-rata hasil belajar postest matematika peserta didik yang diajarkan menggunakan model pembelajaran guided discovery learning dengan rata-rata hasil belajar matematika peserta didik yang diajarkan menggunakan metode pembelajaran ceramah variasi. Oleh karena itu dapat ditarik kesimpulan bahwa model pembelajaran guided discovery learning mempengaruhi hasil belajar dan efektif digunakan sebagai model pembelajaran pada pokok bahasan geometri.
\end{abstract}

Kata Kunci : Model Pembelajaran Guided Discovery Learning, Hasil Belajar Matematika

\begin{abstract}
This research is aimed at showing the effectiveness of the use of a guided discovery learning model on mathematical learning outcomes at a cognitive domain. The research method used is a quasi-experiment with research design of non-equivalent control grup. The research takes 46 samples, consisting of 23 samples for experimental class and 23 samples for control class. The sampling technique used is a nonrandom technique. The type of instrument distributed is a test in the form of 10 essay questions. The result of the research test shows that $H_{1}$ is accepted, meaning there is a difference between the average learning outcomes of mathematics postest of students taught employing guided discovery learning model and those of students taught applying a varied lecture learning method. In conclusion, the guided discovery learning model affects learning outcomes and is effective to be used as a learning model in geometry subject.
\end{abstract}

Keywords : Guided Discovery Learning Model, Mathematical Learning Outcomes

\section{Pendahuluan}

Untuk menciptakan sumber daya manusia yang unggul diperlukan adanya proses pendidikan. Proses pendidikan terdiri dari berbagai unsur yang meliputi, tujuan pendidikan, peserta didik, pendidik, proses pembelajaran, sarana prasarana pembelajaran, waktu pembelajaran maupun lingkungan. Unsur tersebut merupakan satu kesatuan yang tidak dapat dipisahkan sehingga setiap unsur di usahakan berperan seoptimal mungkin untuk memperoleh pendidikan yang berkualitas.

Pendidikan yang berkualitas merupakan tujuan dari setiap proses pendidikan. Pada bidang matematika peserta didik di harapkan memiliki kesiapan pengetahuan dan ilmu untuk pencapaian hasil belajar sesuai tujuan. Hasil belajar matematika peserta didik yang di pelajari merupakan persiapan ke tahap proses belajar selanjutnya. Hasil belajar merupakan indikator keberhasilan peserta didik untuk mencapai tujuan yang diinginkan.

Hasil penelitian Mutoharoh (2011) menunjukkan pembelajaran matematika yang dijumpai di sekolah umumnya lebih mengedepankan pengetahuan daripada ketrampilan dan sikap. 
Peserta didik hanya menerima informasi dari guru sehingga kurang terlibat dalam proses pembelajaran. Kurangnya partisipasi mengakibatkan anak kurang lebih mengutamakan kemampuan menghafal dan mengingat sehingga hasil belajar menjadi kurang optimal. Zaini (2010) menjelaskan bahwa kemampuan mengingat dengan menemukan konsepnya sendiri dapat bertahan lebih lama daripada mendengarkan orang lain. Tabel dibawah merupakan dokumentasi selama 3 tahun terakhir di sekolah MA Ash-shoheh untuk jurusan IPS.

Tabel 1 Rata-rata Nilai UN Matematika

\begin{tabular}{ll}
\hline Tahun & Nilai UN Matematika \\
\hline 2013 & 7.50 \\
2014 & 6,75 \\
2015 & 7.00 \\
\hline
\end{tabular}

Tampak pada tabel 1 dapat dilihat bahwa nilai rata rata pada pelajaran matematika mengalami kelabilan. Hal tersebut dikarenakan proses pembelajaran yang kurang optimal.

Keberhasilan hasil belajar matematika peserta didik memang tidak terlepas dari proses pembelajaran. Dalam hal ini guru memegang peran penting dalam suatu proses pembelajaran. Guru merupakan bagian dari sumber daya pendidikan yang sangat menentukan keberhasilan sebuah pendidikan. Guru menentukan salah satu komponen dalam proses pembelajaran sebagai pendidik dan tenaga kependidikan, karena menurut Djamarah (2012:123) guru adalah tenaga pendidik yang memberikan ilmu pengetahuan kepada peserta didik di sekolah sesuai bidang profesinya. Namun pada kenyataan peranan guru dalam hal ini masih sangat di sayangkan karena guru tidak memiliki kompetensi yang cukup untuk menjalankan proses pembelajaran yang di harapkan. Pendidik dan ketenaga pendidikan adalah kunci dalam dalam peningkatan mutu pendidikan. Apabila pendidik memiliki kompetensi yang cukup maka proses pembelajaran di kelas akan berhasil sehingga terjadi interaksi antara peserta didik dan guru yang terjalin efektif. Sehingga mempermudah peserta didik dalam menyerap dan memahami materi matematika yang telah di berikan.

Dalam proses pembelajaran matematika di sekolah MA Ash-shoheh X IPS masih terfokus pada peranan guru yang lebih dominan dan kurang mengoptimalkan kemampuan peserta didik untuk mengeksplor diri dan belajar mandiri. Pada hasil penelitian Dewi (2014:3) di sekolah khususnya Madrasah Aliyah menyatakan bahwa peserta didik cenderung pasif dan kurang mandiri terhadap peoses pembelajaran serta menunggu perintah dari guru. Hal ini mengakibatkan pemikiran peserta didik tidak mengalami kemajuan. Ketidak majuan cara berpikir ini diakibatkan oleh guru yang memberikan pembelajaran dengan cara memberikan segudang rumus dan konsep konsep atau teorema yang harus dihafalkan oleh peserta didik.

Bukan hanya itu yang menjadi alasan proses pembelajaran tidak optimal, ketakutan dan tekanan peserta didik terhadap pembelajaran matematika suka terjadi sehingga menghilangkan sikap keaktifan peserta didik. Ketakutan dan tekanan karena guru kurang memberi kesempatan berpendapat kepada peserta didik. Proses pembelajaran yang seperti itu bertolak belakang dengan kurikulum 2013 yang mengsyaratkan peserta didik dituntut untuk aktif.

Model pembelajaran juga menjadi salah satu faktor yang mempengaruhi hasil belajar peserta didik. Bentuk pembelajaran yang secara umum diberikan pada pembelajaran khususnya pada mata pelajaran geometri adalah salah satunya adalah metode pembelajaran ceramah variasi. Dengan metode pembelajaran ceramah variasi akan menjadikan peserta didik pasif dan sulit memperoleh hasil belajar yang optimal. Menurut Muntasir (2012:201) sistem penyampaian pembelajaran yang seperti ini disebut system pembelajaran tradisional. Meskipun sistem 
pembelajaran yang demikian bukan hal yang salah, idealnya proses pembelajaran yang baik akan menempatkan guru sebagai pengelola bukan sebagai pemberi informasi satu satunya. Dalam pelaksanaan proses pembelajaran yang seperti itu menimbulkan kendala, yaitu guru terlalu mendominasi sebagian besar aktivitas pembelajaran, sementara peserta didik tidak banyak beraktivitas atau teacher centre dan perolehan materi peserta didik bisa menjadi sangat terbatas karena terlalu mengandalkan keterangan guru.

Untuk memperbaiki proses pembelajaran dalam kegiatan belajar mengajar yang seperti itu. Di perlukan upaya atau usaha untuk mengalihkan teacher centre menjadi student centre yang lebih menekankan pada perkembangan kemampuan berpikir dan memecahkan suatu masalah. Peserta didik harus di arahkan dan di bimbing supaya dapat berpikir kritis, mandiri serta menemukan konsep yang mampu di pahami dirinya sendiri. Salah satu model pembelajaram yang bersifat student centre, mengarahkan, mampu menemukan sebuah konsep dan mampu berpikir kritis peserta didik adalah model pembelajaran Guided Discovery Learning.

Model Pembelajaran Guided Discovery Learning adalah salah satu model pembelajaran yang di anjurkan dalam Kurikulum 2013. Tjipto (2014) Kurikulum 2013 berbasis sainstifik yaitu mengamati, bertanya, menalar, mencoba dan mengkomunikasikan. Langkah langkah tersebut menuntut peserta didik untuk aktif dalam kegiatan belajar, serta menurut Candra dkk (2012:27) model pembelajaran Guided Discovery Learning yang merupakan kegiatan pembelajaran yang melibatkan secara maksimal seluruh kemampuan peserta didik untuk mencari dan menemukan suatu (benda, manusia, peristiwa) secara sistematis, kritis, logis, analisis sehingga peserta didik dapat merumuskan sendiri penemuannya dengan penuh percaya diri. Oleh karena itu, model pembelajaran ini diharapkan dapat memberi manfaat bagi peserta didik agar mendapatkan hasil belajar yang semakin optimal.

\section{Tinjauan Pustaka}

\section{Hakikat Hasil Belajar Matematika}

Setiap individu butuh belajar untuk memperbaiki diri yang meliputi perbaikan pengetahuan dan tingkah laku.Perbaikan tingkah laku diperoleh dari belajar yang diperoleh pengalaman yang telah diperolehnya. Hal ini sependapat dengan Djamarah (2002:11) yang mengatakan bahwa belajar adalah proses perubahan perilaku berkat pengalaman dan latihan artinya tujuan kegiatan adalah perubahan tingkah laku, baik yang menyangkut pengetahuan, kemampuan maupun sikap, bahkan meliputi segenap aspek organisme atau pribadi. Menurut Tri (Hamalik, 2004) Belajar adalah memodifikasi atau memperteguh kelakuan melalui pengalaman (Learning is defined as the modification or strengthening of behavior through experiencing) dan belajar adalah proses perubahan tingkah laku individu melalui interaksi dengan lingkungannya.

Setelah melalui proses belajar di perolehlah hasil belajar. Hasil belajar adalah ukuran pencapaian atau penilaian, sesuai dengan Miftah dan Huri (dalam leonard, 2015:31) Hasil belajar merupakan tolak ukur dalam menentukan berhasil atau tidaknya suatu proses belajar mengajar. Setelah mengalami proses belajar peserta didik mengalami perubahan kemampuan dikarenakan telah mendapatkan informasi yang di cerminkan dengan hasil dari penerimaan informasi yang telah di perolehnya. Hasil belajar merupakan kemampuan yang telah dimiliki setelah melewati proses pembelajaran. Hal teresebut sesuai dengan Sudjana (Lestari, 2012:172) hasil belajar adalah kemampuan yang dimiliki peserta didik setelah ia menerima pengalaman belajarnya. Senada dengan Miftah dan Huri (dalam Leonard,2015:277) yaitu hasil belajar adalah kemampuan yang dimiliki peserta didi setelah peserta didik aktif mengikuti proses pembelajaran.

Hasil belajar mencakup 3 aspek, yaitu kognitif, afektif, dan psikomotorik. Menurut 
Sudjana (dalam leonard (2015:223)) mengatakan hasil belajar adalah perubahan tingkah laku yang mencakup aspek kognitif, afektif dan psikomotorik. Menurut Indriyanto (2008:10):"Semula peserta didik memiliki kemampuan pra belajar, dalam proses belajar peserta didik meningkatkan tingkat atau memperbaiki ranah ranah kognitif, afektif, psikomotorik, yang pada ranah tersebutdi dasarkan atas evaluasi guru dan ujuk kerja peserta didik dalam pemecahan masalah".

Perubahan tingkah laku pada aspek kognitif berkaitan dengan pengetahuan dan pemikiran.Aspek afektif berkaitan dengan sikap, sedangkan aspek psikomotorik berkaitan dengan ketrampilan dan gerak tubuh.Dari ketiga aspek tersebut, aspek kognitif yang lebih sering diperhatikan dalam menilai hasil belajar matematika. Menurut Desiyani dan Yunita ( dalam Leonard, 2015,178) hasil belajar matematika adalah hasil yang dicapai peserta didik sebagai bukti keberhasilan proses belajar matematika yang dialami peserta didik dalam pengetahuan, ketrampilan, sikap, dan nilai.

Hasil belajar matematika menurut Huri (2011:32) adalah puncak dari kegiatan belajar yang berupa perubahan dalam bentuk kognitif, afektif, dan psikomotorik dalam hal kemampuan tentang bilangan bangun, hubungan-hubungan konsep dan logika yang saling berkesinambungan serta dapat diukur.

Dari teori-teori diatas dapat disimpulkan bahwa hasil belajar matematika adalah hasil yang dicapai peserta didik sebagai bukti keberhasilan belajar berupa perubahan dalam bentuk kognitif, afektif, dan psikomotorik dalam hal kemampuan memecahkan masalah pada pembelajaran matematika.

\section{Hakikat Model Pembelajaran Guided Discovery Learning}

Model pembelajaran adalah salah satu cara atau langkah yang digunakan oleh guru yang bertujuan untuk membantu siswa mencapai tujuan pembelajaran. Menurut Komalasari (2010:57) model pembelajaran pada dasarnya merupakan bentuk pembelajaran yang tergambar dari awal sampai akhir yang disajikan secara khas oleh guru. Menurut Mayer (2004 (dalam Antonius dan Woro, 2012:50) Guided Discovery learning merupakan salah satu model pembelajaran yang bertujuan melatih peserta didik untuk menemukan konsep secara mandiri.Peserta didik belajar aktif dalam kegiatan belajar dengan menjawab persoalan dan memecahkan persoalan untuk menemukan sebuah konsep.

Model pembelajaran Guided Discovery learning menurut Eggen (2012: 177) adalah salah satu pendekatan mengajar dimana guru memberi peserta didik contoh contoh topic spesifik dan memandu peserta didik untuk memahami topic tersebut. Menurut Sapriati (2009:128) ada dua macam atau jenis pembelajaran penemuan, yaitu: "Model pembelajaran penemuan murni (free discovery) dan model pembelajaran penemuan terarah atau terbimbing (guided discovery). Model pembelajaran murni merupakan model pembelajaran tanpa adanya petunjuk atau arahan. Sedangkan penemuan terbimbing (guided discovery) merupakan model embelajaran yang membutuhkan peran guru sebagai fasilisator dalam proses pembelajarannya. Pembelajaran penemuan terbimbing lebih banyak di terapkan dibandingkan dengan pembelajaran penemuan murni, karena dalam pembelajaran penemuan terbimbing gurua akan memberikan petunjuk kepada peserta didik sehingga peserta didik akan lebih terarah dalam rangka mencapai tujuan yang telah di tetapkan".

Berdasarkan uraian diatas model pembelajaran Guided Discovery Learning adalah model pembelajaran yang mampu memberikan sebuah penemuan konsep yang di dapatkan oleh peserta didik dengan cara penemuan mereka yang telah dibimbing untuk memudahkan peserta didik memahami materi yang di dapatkan. 
Model pembelajaran Guided Discovery Learning memiliki kelemahan dan kelebihan dalam proses kegiatan pembelajaran. Menurut eggen dan kauchak (2012:211) kelemahan model pembelajaran ini cenderung menyita lebih banyak waktu dan apabila peserta didik tidak mendengarkan secermat yang seharusnya, mereka kerap memiliki konsepsi keliru tentang topic yang mereka pelajari. Kelebihan model pembelajaran ini menurut Menurut Eggen dan Kauchak (2012:211) adalah apabila model pembelajaran ini dilaksanakan dengan baik maka akan menghasilkan pemahaman konsep yang mendalam pada peserta didik dan menghasilkan penyimpanan jangka panjang yang baik, serta mendorong peserta didik berpikir kritis.

Langkah-langkah dalam pembelajaran model guided discovery learning dari pendapat Eggen dan Kauchak dapat disimpulkan, yaitu: (1) Pendahuluan, guru berusaha untuk menarik perhatian peserta didik supaya fokus pada pembelajaran. (2) guru memberikan contoh dan noncontoh suatu konsep untuk mendorong peserta didik lebih aktif bertanya. (3) guru membuat pertanyaan yang lebih spesifik untuk membimbing peserta didik mendapatkan konsep dan ke (4) Guru membantu peserta didik untuk lebih memahami konsep dan menerapkan konsep yang telah diperoleh.

\section{Metodelogi Penelitian}

Penelitian ini di laksanakan di Madrasah Aliyah Ash-Shoheh yang beralamat di Jalan Mayor Oking Jayaatmaja, Puspanegara, Citeurep, Bogor. Penelitian ini dilaksanakan pada semester genap tahun ajaran 2015/2016 yang dimulai pada bulan maret sampai juni 2016.

Jenis penelitian yang di gunakan dalam penelitian ini adalah quasi experiment atau eksperimen semu. Sugiyono (2014:114) tujuan dari eksperimen untuk memperoleh informasi yang dapat di peroleh dari eksperimen yang sebenarnya dalam keadaan yang tidak memungkinkan untuk mengontrol semua variabel. Karena dalam quasi eksperimen ini merupakan model penelitian yang tidak memungkinkan penelitian untuk mengontrol semua variabel maka hanya dilakukan pada variabel yang paling dominan. Dalam pelaksanaan penelitian melibatkan 2 kelompok, yaitu kelompok eksperimen dan kelompok kontrol. Dimana kelompok eksperimen menerapkan model pembelajaran Guided Discovery Learning dan kelompok kontrol menerapkan metode pembelajaran ceramah bervariasi.

Tabel 2 Rancangan Penelitian Non Equivalent Control Grup Design

\begin{tabular}{lllll}
\hline Kelompok & Kelas & Pretest & Treatment & Postest \\
\hline Eksperimen & X IPS 1 & $\mathrm{O}_{1}$ & $\mathrm{X}$ & $\mathrm{O}_{2}$ \\
Kontrol & X IPS 3 & $\mathrm{O}_{3}$ & - & $\mathrm{O}_{4}$ \\
\hline
\end{tabular}

$\begin{array}{ll}\text { Keterangan: } & \\ \mathrm{O}_{1} & : \text { Hasil tes awal kelas eksperimen } \\ \mathrm{O}_{2} & \text { : Hasil tes akhir kelas eksperimen } \\ \mathrm{O}_{3} & : \text { Hasil tes awal kelas control } \\ \mathrm{O}_{4} & \text { : Hasil tes akhir kelas control } \\ \mathrm{X} & \text { :Treatment yang diberikan kepada kelompok eksperimen } \\ & \text { dengan model pembelajaran Guided Discovery Learning }\end{array}$

Populasi pada penelitian ini adalah peserta didik kelas X IPS MA Ash-shoheh, Citeurep tahun ajaran 2015/2016.Dalam penelitian ini menggunakan sampel dari populasi kelas X IPS 1 yang berjumlah 23 orang dan kelas X IPS 3 yang berjumlah 23 orang. Teknik sampling yang dipilih dalam penelitian ini adalah teknik sampling nonrandom. Satu kelas akan menjadi kelas eksperimen dengan menggunakan model pembelajaran Guided Discovery 
Learning dan satu kelas lagi menjadi kelas kontrol dengan menggunakan metode pembelajaran ceramah bervariasi.

\section{Hasil dan Pembahasan \\ Hasil Penelitian Kelas Eksperimen}

Penelitian pada kelas eksperimen dilakukan pada kelas X IPS 1 dengan jumlah peserta didik sebanyak 23 anak. Dalam kefektifan peneliti melihat pada aspek kognitif yaitu hasil belajar peserta didik. Untuk mengetahui seberapa besar kemampuan kognitif anak pada pembelajaran geometri adalah melakukan pretest, pretest pada penelitian dilakukan sebelum perlakuan model pembelajaran oleh guru. Kemudian setelah melaksanakan model pembelajaran Guided Discovery Learning pada akhir pertemuan pada materi ajar geometri dilaksanakannya posttest berupa soal uraian yang mencakup isinya sesuai standar kompetensi yang ada pada silabus . Pada tabel 3 menerangkan mengenai rangkuman hasil perolehan data posttest pada kelas eksperimen.

Tabel 3 Tabel Distribusi Frekuensi Kelas Eksperimen (postest)

\begin{tabular}{|c|c|c|c|c|c|c|}
\hline Nilai interval & Frekueni & Nilai tengah & f.xi & $x i-\dot{x}$ & $(\mathrm{xi}-\dot{\mathrm{x}})^{2}$ & Fi. $(x i-\dot{x})^{2}$ \\
\hline $60-64$ & 5 & 62 & 310 & $-10,87$ & 118,16 & 590,78 \\
\hline $65-69$ & 3 & 68 & 204 & $-4,87$ & 23,72 & 71,15 \\
\hline $70-74$ & 6 & 72 & 432 & $-0,87$ & 0,76 & 4,54 \\
\hline $75-79$ & 2 & 78 & 156 & 5,13 & 26,32 & 52,63 \\
\hline $80-84$ & 7 & 82 & 574 & 9,13 & 83,36 & 583,50 \\
\hline Jumlah & 23 & & 1.676 & & 252,30 & $1.302,61$ \\
\hline
\end{tabular}

Dari data yang telah diperoleh dapat disimpulkan bahwa hasil tes 23 peserta didik pada kelas eksperimen (postest) yaitu rentang nilai 84 - 60 dengan nilai rata rata 73,09, median 72,93, modus 72,15 , varian 56,71 dan simpangan baku 7,53. Hal tersebut menunjukkan rata rata nilai tinggi.

Tabel 4 Skor N-Gain Kelas Eksperimen

\begin{tabular}{llllll}
\hline No & Pretes & Postes & Selisih & N-gain & Keterangan \\
\hline 1 & 50 & 78 & 28 & 0.82 & Tinggi \\
2 & 48 & 70 & 22 & 0.61 & Sedang \\
3 & 40 & 64 & 24 & 0.55 & Sedang \\
4 & 50 & 68 & 18 & 0.53 & Sedang \\
5 & 62 & 74 & 12 & 0.55 & Sedang \\
6 & 38 & 60 & 22 & 0.48 & Sedang \\
7 & 52 & 74 & 22 & 0.69 & Sedang \\
8 & 54 & 80 & 26 & 0.87 & Tinggi \\
9 & 42 & 70 & 28 & 0.67 & Sedang \\
10 & 50 & 74 & 24 & 0.71 & Tinggi \\
11 & 34 & 64 & 30 & 0.60 & Sedang \\
12 & 70 & 82 & 12 & 0.86 & Sedang \\
13 & 58 & 74 & 16 & 0.62 & Sedang \\
14 & 64 & 68 & 4 & 0.20 & Rendah \\
15 & 76 & 80 & 4 & 0.50 & Sedang \\
16 & 58 & 78 & 20 & 0.77 & Tinggi \\
17 & 44 & 64 & 20 & 0.50 & Sedang \\
18 & 34 & 62 & 28 & 0.56 & Sedang \\
19 & 80 & 82 & 2 & 0.50 & Sedang \\
20 & 64 & 80 & 16 & 0.80 & Tinggi \\
21 & 46 & 84 & 38 & 1.00 & Tinggi \\
22 & 62 & 68 & 6 & 0.27 & Rendah \\
23 & 80 & 84 & 4 & 1.00 & Tinggi \\
\hline
\end{tabular}

Berikut disajikan rangkuman perolehan nilai postest untuk kelas kontrol pada tabel 5 . 
Tabel 5 Tabel Distribusi Frekuensi Kelas Kontrol (postest)

\begin{tabular}{|c|c|c|c|c|c|c|}
\hline Nilai interval & Frekueni & Nilai tengah & f.xi & $x i-\dot{x}$ & $(x i-\dot{x})^{2}$ & Fi. $(x i-\dot{x})^{2}$ \\
\hline $56-60$ & 4 & 58 & 232 & -9.57 & 91.58 & 366.34 \\
\hline $61-65$ & 5 & 63 & 315 & -4.57 & 20.88 & 104.42 \\
\hline $66-70$ & 6 & 68 & 408 & 0.43 & 0.18 & 1.11 \\
\hline $71-75$ & 5 & 73 & 365 & 5.43 & 29.48 & 147.42 \\
\hline $76-80$ & 3 & 78 & 234 & 10.43 & 108.78 & 326.35 \\
\hline Jumlah & 23 & & 1554 & & 250.92 & 945.65 \\
\hline
\end{tabular}

Dari data yang telah diperoleh dapat disimpulkan bahwa hasil tes 23 peserta didik pada kelas kontrol (postest) yaitu rentang nilai 80 - 60 dengan nilai rata rata 67,57, median 67,58, modus 68,0 , varian 42,98 dan simpangan baku 6,55 .

Tabel 6 Skor N-gain Pada Kelas Kontrol

\begin{tabular}{llllll}
\hline No & Pretes & Postes & Selisih & N-gain & Keterangan \\
\hline 1 & 60 & 80 & 20 & 1.00 & Tinggi \\
2 & 50 & 76 & 26 & 0.87 & Tinggi \\
3 & 44 & 60 & 16 & 0.44 & Sedang \\
4 & 36 & 56 & 20 & 0.45 & Sedang \\
5 & 44 & 80 & 36 & 1.00 & Tinggi \\
6 & 52 & 60 & 8 & 0.29 & Rendah \\
7 & 40 & 62 & 22 & 0.55 & Sedang \\
8 & 40 & 72 & 32 & 0.80 & Tinggi \\
9 & 54 & 64 & 10 & 0.38 & Sedang \\
10 & 44 & 56 & 12 & 0.33 & Sedang \\
11 & 50 & 72 & 22 & 0.73 & Tinggi \\
12 & 50 & 70 & 20 & 0.67 & Tinggi \\
13 & 52 & 72 & 20 & 0.71 & Tinggi \\
14 & 34 & 64 & 30 & 0.65 & Tinggi \\
15 & 52 & 70 & 18 & 0.64 & Tinggi \\
16 & 50 & 70 & 20 & 0.67 & Tinggi \\
17 & 62 & 64 & 2 & 0.11 & Rendah \\
18 & 60 & 62 & 2 & 0.10 & Rendah \\
19 & 22 & 66 & 44 & 0.76 & Tinggi \\
20 & 62 & 70 & 8 & 0.44 & Sedang \\
21 & 44 & 72 & 28 & 0.78 & Tinggi \\
22 & 34 & 70 & 36 & 0.78 & Tinggi \\
23 & 50 & 72 & 22 & 0.73 & Tinggi \\
\hline
\end{tabular}

\section{Persyaratan Analisis Data}

Setelah dilakukan pengolahan data, maka selanjutnya di lakukan uji normalitas menggunakan uji lilliefors terhadap data nilai postest pada kelas eksperimen maupun kelas kontrol. Berdasarkan hasil perhitungan pada kelas eksperimen didapat $L o=0,1062<$ $L_{\text {tabel }}=0,1798$ maka $H_{o}$ di terima, yang berarti data berdistribusi normal. Sedangkan pada kels kontrol didapat hasil $L o=0,1062<L_{\text {tabel }}=0,1798$ maka $\boldsymbol{H}_{\boldsymbol{o}}$ di terima, yang berarti data berdistribusi normal. Sedangkan untuk uji homogenitas dilakukan dengan uji F(Fisher) dimana varians kelas eksperimen akan dibandingkan dengan varians kelas kontrol. Tabel 5 merupakan hasil varians dari kelas eksperimen dan kontrol terhadap hasil data postest.

\section{Tabel 7 Data Varians Tiap Kelas (postest)}

\begin{tabular}{lll}
\hline & Nilai Varian & $\mathrm{N}$ \\
\hline Eksperimen & 59.21 & 23 \\
Kontrol & 42.98 & 23 \\
\hline
\end{tabular}


Berdasarkan hasil perhitungan, diprolehan $F_{\text {hitung }}=1,378$ dan $F_{\text {tabel }}=2,05$, maka $F_{\text {hitung }}=1,378<F_{\text {tabel }}=2,05$ sehingga $H_{0}$ diterima yang berarti data homogen.

\section{Pengujian Hipotesis}

Pengujian hipotesis yang digunakan dalam penelitian adalah uji t-test untuk dua kelompok data dari dua kelompok sampel yaitu kelompok eksperimen dan kelompok kontrol. Dengan hipotesis:

$H_{o}: \mu_{A}=\mu_{B}$

$H_{O}: \mu_{A} \neq \mu_{B}$

$\mu_{A} \quad$ : Rata-rata hasil belajar postest matematika peserta didik yang diajarkan dengan menggunakan model pembelajaran Guided Discovery Learning .

$\mu_{B} \quad$ : Rata-rata hasil belajar postest matematika peserta didik yang diajarkan dengan menggunakan model pembelajaran konvensional.

Berikut perhitungan uji t-test:

Diketahui :

$S_{A}^{2}$ ( Varians Kelompok Eksperimen (postest))

$S_{B}^{2}$ ( Varians Kelompok Kontrol (postest))

$\bar{X}_{A}$ (Rata-rata Kelompok Eksperimen (postest))

$\bar{X}_{B}$ (Rata-rata Kelompok Kontrol (postest))

a. Simpangan baku gabungan

$$
\begin{aligned}
S_{\text {gab }} & =\sqrt{\frac{\left(n_{A}-1\right) S_{A}^{2}+\left(n_{B}-1\right) S_{B}^{2}}{n_{A}+n_{B}-2}} \\
& =\sqrt{\frac{(23-1) 59,21+(23-1) 42,98}{23+23-2}} \\
& =\sqrt{\frac{(22) 59,21+(22) 42,98}{44}} \\
& =\sqrt{\frac{1302,62+945,56}{44}} \\
& =\sqrt{51,01} \\
& =7,14
\end{aligned}
$$

b. $t_{\text {hitung }}$

$$
\begin{aligned}
t & =\frac{\bar{X}_{A}-\bar{X}_{B}}{s_{g a b} \sqrt{\frac{1}{n_{A}}+\frac{1}{n_{B}}}} \\
& =\frac{72,87-67,57}{7,14 \sqrt{\frac{1}{23}+\frac{1}{23}}} \\
& =\frac{5,3}{7,14 \sqrt{0,087}} \\
& =\frac{5,3}{7,14 \cdot 0,295} \\
& =\frac{5,3}{2,1063}=2,516
\end{aligned}
$$


Diperoleh $t_{\text {hitung }}=2,516$ dan $t_{\text {tabel }}$ diperoleh dengan taraf $a=0,05$ dan $d k=n_{A}+n_{B}-$ 2 sehingga didapatkan $t_{\text {tabel }}=2,016$. Berdasarkan kriteria uji hipotesis:

Tolak $H_{0}$ jika $t_{\text {hitung }}>t_{\text {tabel }}$; dan

Terima $H_{0}$ jika $t_{\text {hitung }}<t_{\text {tabel }}$

Karena $t_{\text {hitung }}=2,516>t_{\text {tabel }}=2,016$ maka $H_{0}$ ditolak, yang berarti $H_{1}$ diterima sesuai dengan hipotesis statistik sebagai berikut:

$$
\begin{aligned}
& H_{0}: \mu_{A} \leq \mu_{B} \\
& H_{1}: \mu_{A}>\mu_{B}
\end{aligned}
$$

Dapat disimpulkan bahwa $H_{1}$ diterima yang menunjukkan bahwa "Adanya perbedaan antara rata-rata hasil belajar postest matematika peserta didik yang diajarkan menggunakan model pembelajaran Guided Discovery Learning dengan rata-rata hasil belajar matematika peserta didik yang diajarkan menggunakan metode pembelajaran ceramah variasi"

Kesimpulan $H_{1}$ diterima memberi arti bahwa model pembelajaran Guided Discovery Learning memberikan kontribusi yang baik terhadap kemampuan matematika peserta didik khususnya pada pokok bahasan geometri dengan tes uraian.

Berdasarkan data hasil penelitian dan analisis data penelitian ini bertujuan untuk mengetahui pengaruh penggunaan model pembelajaran Guided Discovery Learning pada materi geometri kelas X IPS dengan membandingkan penggunaan metode pembelajaran ceramah variasi. Hasil belajar matematika yang diajarkan dengan menggunakan model pembelajaran Guided Discovery Learning juga lebih tinggi dari pada hasil belajar matematika menggunakan metode pembelajaran ceramah variasi. Hal tersebut dibuktikan dari hasil pengujian hipotesis pada data postest dengan menggunakan uji-t diperoleh nilai $t_{\text {hitung }}=2,516$ sedangkan $t_{\text {tabel }}=2,016$ pada taraf signifikan $a=0,05$, maka $t_{\text {hitung }}>t_{\text {tabel }}$ sehingga $H_{O}$ ditolak atau $H_{1}$ diterima. Hasil ini diperkuat oleh penelitian yang dilakukan Evi Alinda dengan judul "Perbandingan hasil belajar matematika siswa antara yang diajar dengan metode penemuan terbimbing dan metode ekspositori". Berdasarkan uji hipotesis $t_{\text {hitung }}=$ $4,843>t_{\text {tabel }}=2,025$ maka dapat disimpulkan bahwa hasil beajar matematika dengan metode penemuan terbimbing lebih tinggi dibanding hasil belajar matematika menggunakan metode ekspositori. Dengan arti lain bahwa metode penemuan terbimbing mampu mempengaruhi hasil belajar matematika peserta didik.

Dilanjutkan dengan penelitan yang dilakukan oleh 2 Firdaus, Hera Deswita dan Arcat pada penelitiannya yang berjudul "Pengaruh Model Pembelajaran Penemuan Terbimbing ( Guided Discovery Learning ) terhadap Hasil Belajar Matematika Siswa Kelas VIII SMP Negeri 2 pada Materi Persegi Panjang dan Segitiga " pada tahun 2015. Berdasarkan uji hipotesis t_hitung= 2,18 > t_tabel=2,02, sehingga dapat disimpulkan bahwa model pembelajaran Penemuan Terbimbing ( Guided Discovery Learning ) mempengaruhi Hasil Belajar Matematika Siswa Kelas VIII SMP Negeri 2 Kepenuhan pada Materi Persegi Panjang dan Segitiga.

Berdasarkan data deskriptif dan penelitian yang relevan, model pembelajaran Guided Discovery Learning ini mampu mempengaruhi hasil belajar matematika peserta didik dan efektif pada proses pembelajaran dari pada metode pembelajaran cermah bervariasi. Hal tersebut terjadi dikarenakan hasil perhitungan rata-rata pada kelas yang menggunakan model pembelajaran Guided Discovery Learning dengan yang menggunakan metode pembelajaran cermah bervariasi. Hal tersebut tidak terjadi secara kebetulan, tetapi terjadi karena perlakuan kelas dengan model pembelajaran yang berbeda, selain itu faktor-faktor eksternal atau internal menjadi pengaruh terhadap hasil sebuah keberhasilan hasil kerja peserta didik. Kemudian, pemahaman konsep dan berpikir kritis serta kemampuan analisa peserta didik 
yang merupakan output dari hasil belajar dengan Guided Discovery Learning akan memberikan dampak yang positif bagi peserta didik dimasa kedepan, yang demikian merupakan benih awal untuk meraih mutu dan hasil pendidikan yang baik dan optimal. Dari hasil pengujian skor gain dengan menggunakan rumus N-gain menunjukkan bahwa peningkatan yang diperoleh peserta didik yang menggunakan model pembeljaran Guided Discovery Learning lebih banyak yang memperoleh kategori tinggi dibandingkan dengan yang menggunakan metode ceramah bervariasi.

Berdasarkan pembahasan yang telah diuraikan maka diperoleh kesimpulan yaitu hasil belajar peserta didik pada pembelajaran matematika dengan pokok bahasan "geometri" dengan model pembelajaran Guided Discovery Learning sangat berpengaruh dan efektif dalam pembelajaran matematika serta dapat meningkatkan hasil belajar matematika di MA Ashshoheh.

\section{Simpulan dan Saran \\ Simpulan}

Berdasarkan dari hasil pengujian hipotesis dan analisis data hasil penelitian dengan judul efektivitas model pembelajaran Guided Discovery Learning tehadap hasil belajar matematika kelas XI IPS MA Ash-shoheh disimpulkan bahwa adanya pengaruh model pembelajaran Guided Discovery Learning dengan pendekatan saintifik terhadap hasil belajar matematika dengan penolakan $H_{O}$ dan diterimanya $H_{1} . H_{1}$ berisi adanya perbedaan rerata peserta didik yang menggunakan model pembelajaran Guided Discovery Learning dan peserta didik yang menggunakan metode pembelajaran ceramah variasi. Adanya pengaruh hasil belajar (postest) dengan model pembelajaran Guided Discovery Learning dapat disimpulkan pula bahwa selain berpengaruh model pembelajaran Guided Discovery Learning juga efektif untuk dilakukan pada proses pembelajaran khususnya pada materi geometri.

\section{Saran}

Berdasarkan uraian di atas, saran yang dapat penulis sampaikan terkait hasil penelitian, yaitu:

1. Praktisi pendidikan, khususnya pihak-pihak yang telibat langsung dalam pembelajaran disarankan agar menerapkan model guided discovery learning untuk memberikan pengalaman belajar yang bermakna, membangun pengetahuan siswa dan meningkatkan hasil belajar.

2. Praktisi Peserta pendidikan, khususnya pihak - pihak yang telibat dalam pembelajaran matematika disarankanagar menerapkan model guided discovery learning untuk meningkatkan keterllibatansiswa dan kualitas proses pembelajaran matematika.

3. Kepada sekolah, hendaknya hasil penelitian ini dapat digunakan sebagai informasi yang berharga untuk pengambilan kebijakan dalam lembaga pendidikan dalam upaya meningkatkan proses pembelajaran di sekolah.

4. Peneliti yang berminat dapat melakukan penelitian model guided discovery learning dalam ruang lingkup mata pelajaran lain untuk dapat memberikan pengalaman secara langsung mengenai pentingnya pemilihan model pembelajaran yang tepat dalam pembelajaran

\section{Daftar Pustaka}

Djamarah, Syaiful Bahri.(2006).Strategi Belajar Mengajar. Jakarta: PT Sinar Baru: Bandung Eggen \& Kauchak. (2012). Strategi Dan Model Pembelajaran, Edisi ke-6. Jakarta: Indeks. Gusniwati. (2015). Pengaruh Kecerdasan Emosional dan Minat Belajar Terhadap Penguasaan Konsep Matematika Siswa Sman Di Kecamatan Kebon Jeruk. Jurnal Formatif, Vol. 5 No. 1, April 2015:29. 
Handayani, Sri. Pengaruh Metode Inkuri Terhadap Kreatifitas Belajar Matematika. Skripsi. Jakarta. Unindra PGRI.

Heru Setyawan "Pengertian, Kelebihan, dan Kelemahan Metode Ceramah" dalam http://zonainfosemua.blogspot.com/2011/01/pengertian-kelebihan-dankekurangan.html.

Iswadji, Djoko. (2001). Geometri Ruang. Jakarta: Universitas terbuka.

Lynda D.H \& Nurul H. Penerapan Model Pembelajaran Kooperatif Tipe STAD Terhadap Hasil Belajar Matematika. Dalam Leonard (editor). Edusearch. Vol I. Jakarta: UnindraPress.

Marita K.V. \& Suparlan. Pengaruh Pembelajaran Kooperatif Tipe TGT (Teams Games Tournament) Terhadap Hasil Belajar Matematika. Dalam Leonard (editor). Edusearch. Vol I. Jakarta: UnindraPress.

Marselinus S \& Achiruddin. Pengaruh Model Pembelajaran Contextual Teaching And Learning (CTL) Dalam Pembelajaran. Dalam Leonard (editor). Edusearch. Vol I. Jakarta: Unindra Press.

Mutoharoh, Siti (2011). Pengaruh Model Guided Discovery Learning Terhadap Hasil Belajar Kimia. Jakarta : UIN

Rodiah, Lies. Efektivitas Metode Inquiry Tebimbing Terhadap Hasil Belajar Matematika. Skripsi. Jakarta. Unindra PGRI

Roida e.f.s \& Maya N. Metode Pembelajaran Inquiry dan Pengaruhnya Terhadap Hasil Belajar Matematika Ditinjau Dari Kreativitas Belajar. Jurnal Formatif, Vol. 5 No. 1, April 2015:37.

Slameto.(2010). Belajar dan Factor-Faktor Yang Mempengaruhinya. Jakarta. Rineka Cipta.

Sugiyono. (2014). Metode Penelitian Pendidikan. Bandung: Alfabeta.

Syifa, N.S.W. 2014. Efektivitas Model Pembelajarn NHT Terhadap Hasil Belajar Matematika. Skripsi. Jakarta. Unindra PGRI.

Uno,H. 2007. Model Pembelajaran Menciptakan Proses Belajar Mengajar Yang Kreatif Dan Efektif. Jakarta: Bumi Aksara.

U.S, Supardi. (2016). Aplikasi Statistika Dalam Penelitian. Edisi revisi. Jakarta:Smart.

W. Gulo.2002. Strategi Belajar Mengajar. Jakarta Timur: Grasindo.

Yulia, R. Efektivitas Model Discovery Leraning Untuk Peningkatan Hasil Belajar Siswa Kelas X Pada Kompetensi Dasar Analisis Rangkaian Kemagnetan. Yogyakarta: UNY diunduh pada 1 Desember 2015 pukul. 20.30.

Zaini, H. (2010). Strategi Pembelajaran Aktif. Yogyakarta : Pustaka Insan Mandiri 